\title{
Effectiveness of Removal of Odorous Compounds from a Poultry Farm in a Water Scrubber with Sand Filling
}

\author{
Izabela Wysocka1*, Adam Boguszewicz' \\ 1 Department of Environment Engineering, Faculty of Environmental Sciences,University of Warmia and \\ Mazury in Olsztyn, ul. Warszawska 117, 10-701 Olsztyn, Poland \\ * Corresponding author's e-mail: iwysocka@uwm.edu.pl
}

\begin{abstract}
Breeding facilities are the source of numerous complaints regarding the odor nuisance. For this reason, numerous attempts are made to reduce the odor nuisance of such objects. One of the methods of deodorizing the gases from breeding facilities might be the sorption of odorants in water scrubbers. This article presents the effectiveness of removing this type of impurities from water scrubbers with suspended sand filling. An increase in deodorization efficiency was observed, compared to the water scrubbers without fill ranging from $55 \%$ to $62 \%$, depending on the time of gas contact with the sorbent in the scrubbers.
\end{abstract}

Keywords: deodorization, barbotage column, scrubber water, absorption of filling, odors

\section{INTRODUCTION}

Among the many nuisances and threats appearing with the functioning and development of the economy, the issue of odor nuisance arises. In years $2006-2012$, the complaints regarding odors ranged from $32 \%$ to $67 \%$ of all complaints about air quality in Poland [Kulig et al., 2009; "ODORY - ABC," 2018]. Most often, the sources of emissions of such compounds are related to industrial production, food processing and gastronomy plants, operation on sewage treatment plants, operation on recycling and waste disposal plants, or animal husbandry [Barbusinski et al., 2017; Wysocka I. and Namieśnik J., 2018]. A large part of complaints concerns breeding facilities. Intervention usually confirms the legitimacy of complaints. However, due to the difficulties associated with the enforcement of post-control recommendations, which are usually caused by the lack of legal regulations regarding the obligation to limit odorants, the situation does not change much [Wierzbińska and Modzelewski, 2015]. According to the Statistics Poland data for 2010, 671.4 thousand farms were engaged in the breeding of laying hens and broiler chicken farms 94.1 thousand. This is $29.5 \%$ and $4.1 \%$ of all farms in the country, respectively [Łączyński et al., 2011].

The problem of odour nuisance might be solved in two ways:

- by applying the technologies that ensure the possibility of avoiding or limiting the emission of odorous gases (preventive methods),

- by applying the solutions ensuring the removal of odorous substances in the resulting gases (gas deodorisation).

According to the principle of sustainable development, the problem of odour nuisance is best solved at its source. Here, prevention is one of the most commonly used and preferred methods. In the case of animal husbandry, using appropriate feed, or appropriate breeding systems, and even the settlement of litter with the appropriate bacterial strain is the best solution [Jugowar and Piotrkowski, 2012; Gutarowska et al., 2014; Matusiak et al., 2016]. Unfortunately, this is often not enough. Therefore, it is necessary to deodorize the emerging odorous gases. There are a number of more or less technologically advanced methods. In deodorization methods, the ones based on absorption [Freudenthal et al., 2005], adsorp- 
tion [Cartellieri et al., 2005], thermal treatment [Schlegelmilch et al., 2005], non-thermal oxidation [Mielcarek et al., 2009], biological purification [Ergas and Cárdenas-González, 2004] or the use of admixtures changing the character of the fragrance [Piecuch et al., 2011] might be applied.

Due to the fragmentation of poultry farming, the proposed deodorization methods should be easy to use and relatively inexpensive. Sorption processes are the most frequently performed methods. The sorption material might be properly prepared by activated carbon or natural sorbents populated with appropriate microorganisms (e.g. containing heather, coconut, shells, wood, bark or wood chips). Another way of applying sorption processes are various types of scrubbers proceeded sorption liquids. Most often, they are water solutions. In the case of deodorization, the water itself already provides some degree of reduction of the concentration of odor compounds in the gas to be purified. However, the efficiency of such processes is low [Szynkowska et al., 2009]. Addition of microorganisms (bio-fumes) or chemicals (eg ozone $\left(\mathrm{O}_{3}\right)$, hydrogen peroxide $\left(\mathrm{H}_{2} \mathrm{O}_{2}\right)$, sodium hypochlorite $(\mathrm{NaOCl})$, diluted sodium hydroxide $(\mathrm{NaOH})$, diluted potassium hydroxide $(\mathrm{KOH})$ or sulfuric acid (VI) significantly increases the efficiency of deodorization up to $98 \%$ [Boumnijel et al., 2016]. However, this does not always guarantee the solution of the odor nuisance problem. Due to the very low olfactory thresholds of many substances, even very low concentrations in the purified gas might be a problem. Therefore, the methods dedicated to the specific gases are often sought.

This article presents the effectiveness of removing the odors from gases originating from poultry farming using aqueous bubbling muds with additional filling, i.e. sand. The aim of the research was to estimate the suitability of the proposed solution for deodorization of the gases from breeding processes.

\section{METHODOLOGY}

\section{Research material}

The studies were performed with malodorous gases from the poultry farms, which are located at Słoneczna 5D Street in Olsztyn, Poland at the Department of Poultry Science at the Faculty of Animal Bioengineering at the University of Warmia and Mazury in Olsztyn. The samples were taken from the breeding hall on the last day of raising chickens. The development cycle lasted 14 weeks. The poultry was kept in 60 cages ( $2 \mathrm{~m} \times 2 \mathrm{~m})$. Each cage was covered by sawdust. There were 60 chickens in every chicken coop. Mechanical ventilation was performed in the hall.

\section{Samples}

Malodorous gases were studied in with accordance of PN-EN 13725 [2007] using ECOMA CSD30 ("lung's method") allowing to apply the sample with volume of approximately 8.5 liters. The device was set to continuously repeat the process. The samples of contaminated air (30 samples) were collected for Tedlar bags (placed inside the equipment). All samples were transferred to the laboratory and averaged by pumping into a single large bag (sleeve). Before introducing the gas into the reactors, the large bag was divided into two parts (one for each of the reactors) and this gas was subjected to olfactometric analysis to determine the odor concentration. The odor concentration was $173 \mathrm{ou}_{\mathrm{E}} / \mathrm{m}^{3}$.

\section{Olfactometric analysis}

The odor concentration was determined by a group of panelists with the YES/NO method applying dynamic olfactometry. The group was selected following guidelines of the PN-EN 13725 standard [2007].

The gases were subjected to the olfactometric analysis immediately after collection and averaging of samples as well as immediately after the deodorization.

\section{Research stations}

The gas was continuously extracted into two research stations consisting of the reactors with a capacity of $1000 \mathrm{~cm}^{3}$. The test stands with different sorbent consist the glass reactors filled with $900 \mathrm{~cm}^{3}$ sorption liquid. The first station was a reactor with tap water. It was a comparative reactor. The second station was a tap water reactor with sand (Fig.1). The contaminated gas was distributed applying fine-bubble just below the bottom of each reactor. The gas collected from each position was analyzed olfactometrically. Four measurements of the aromatic concentration value for each position were performed. 


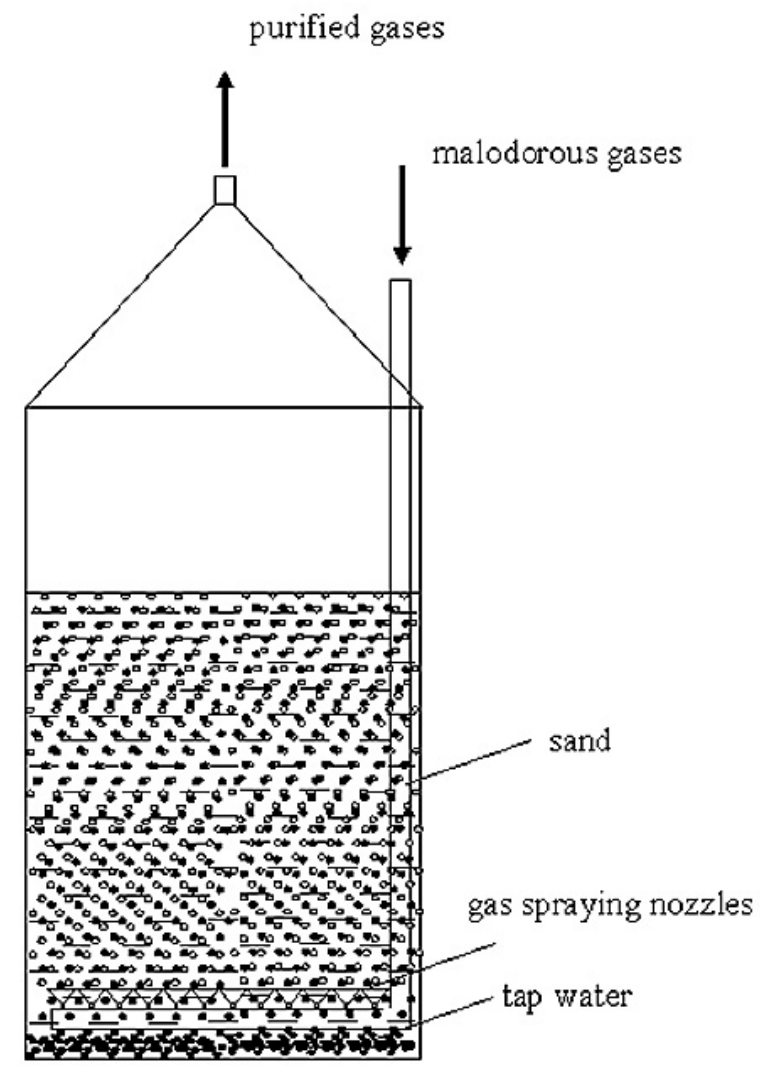

Fig. 1 Diagram of a tap water reactor with sand.

The flow in the reactor was $0.8-12.3 \mathrm{~m}^{3} / \mathrm{s}$.

\section{RESULTS AND DISCUSSION}

In this study, the gases with low pressure of odorant from poultry farm were investigated. The value of the odor concentration of the collected gases was $173 \mathrm{ou}_{\mathrm{E}} / \mathrm{m}^{3}$. A preliminary analysis of the effectiveness of deodorization of the gases in the bubble reactor was carried out. According to the principle of bubble reactors, the gases passed through the absorption of liquid layer. The liquid layer is intensively mixed by the air flow bubbles, which are usually distributed by fine-bubble just below the bottom of the reactor. The gas bubbles migrate through the absorbent layer and are polluted due to the absorption of the contamination. In this work the gas deodorization was carried out through sorption by the gas phase fragmentation in the liquid phase or liquid phase with suspended solid phase (bubbling gas). Two types of phase were applied: a tap water and a tap water with sand. The efficiency of gas purification with tap water was not impressive (It was a comparative position). The efficiency was about $31 \%-45 \%$ (Fig.2). According to the article [Szynkowska et al., 2009] the achieved efficiency is $85 \%$. It is much below the suggested efficiency. It should have been taken into account that during the deodorization experiment, the gases with a low aromatic concentration were applied. With such concentrations, it is difficult to obtain high efficiency [Schlegelmilch et al., 2005].

The odor concentration value after the deodorization process (depending on the flow rate) was $96-119 \quad \mathrm{ou}_{\mathrm{E}} / \mathrm{m}^{3}$ (Fig.3). The concentration was reduced by only 54-77 fragrance units.

Hence, an additional factor has been proposed, in order to improve the results.

The reduction of the odor concentration in the case of using sand filling was from $94 \%$ to even $100 \%$ of the initial concentration (Fig.2). On the other hand, with the largest volume gas flow tested, the concentration was only $11 \mathrm{ou}_{\mathrm{E}} / \mathrm{m}^{3}$ (Fig.3). This value is significantly above the efficiency obtained during the absorption in water [Szynkowska et al., 2009] and comparable to the efficiency achieved with chemically assisted absorption [Biard et al., 2010; Mokhatab and Poe, 2012; Boumnijel et al., 2016]. It should be also noted that the obtained efficiency concerns the purification of the gases with a relatively low aromatic concen- 


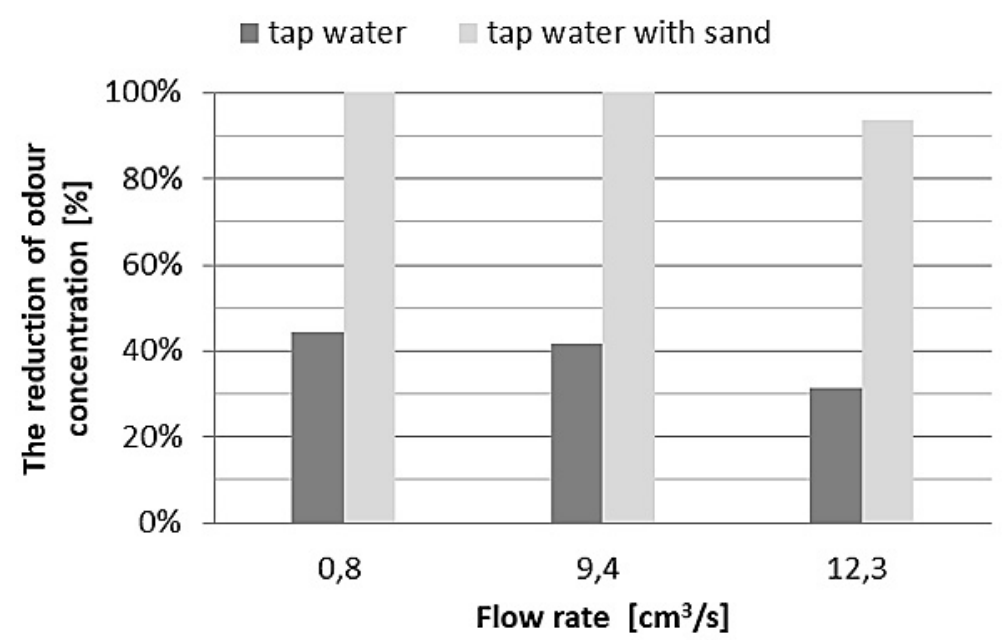

Fig. 2 Reduction of the odor concentration demand for deodorization by sorption in the tap water and the tap water with sand.

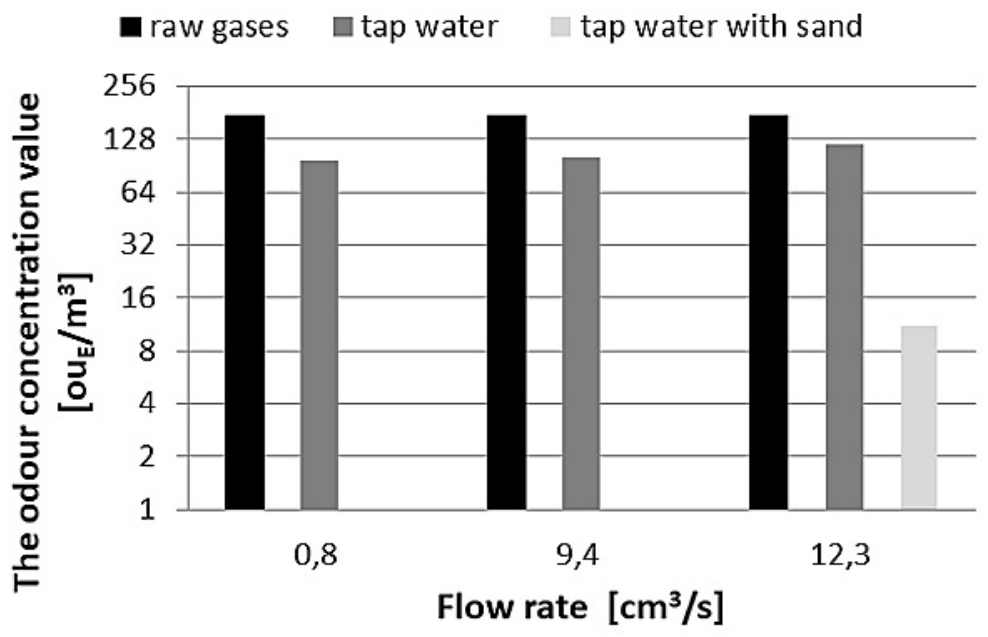

Fig. 3 Changes in the odor concentration in the gas after absorption in tap water and the tap water with sand.

tration. The absorption processes in the water are most often applied as the first level of deodorization due to the limited possibilities of removing low concentration of odorants [Schlegelmilch et al., 2005]. In that case, the method also seems to be effective for small concentrations.

A serious problem for absorbing methods (in particular chemically assisted ones) is the corrosion processes of plant components [Szynkowska et al., 2009]. Applying the proposed solution might significantly reduce the extent of that problem. An additional advantage is the management of wastes generated in the process of deodorization (for example, absorption liquid together with the sludge formed after the deodorization process). In the case of chemically assisted methods, the resulting waste is often a major utilization problem [Schlegelmilch et al., 2005; Szynkowska et al., 2009]. Water with sand applied in the deodorization process might be easier to dispose of.

\section{CONCLUSIONS}

The tests should be considered as preliminary. Nevertheless, they show a significant effect of filling in the deodorization process. Applying the flow of $0.8 \mathrm{~cm}^{3} / \mathrm{s}$, the tap water was able to remove only about $45 \%$ of the substance (up to $96 \mathrm{ou}_{\mathrm{E}} / \mathrm{m}^{3}$ ), while the presence in sand resulted in practically $100 \%$ reduction in the odor concentration, as the odor panel did not detect odorants in samples during the measurements performed in accordance with PN-EN 13725 standard [2007]. In the case of deodorization of gases originating from poultry farming, the proposed method is 
matched by the effectiveness of absorption supported with chemical compounds.

Additionally, absorption processes in aqueous solutions are carried out for the gases containing high odor concentrations [Lu et al., 2012, Couvert et al., 2006]. They do not always guarantee a satisfactory final result [Schlegelmilch et al., 2005]. This study was conducted using relatively low concentrations of gases, suggesting that the proposed method might also be applied for final gas purification processes.

The proposed method does not require proceeding expensive sorbents and utilizes the filling which should not be difficult to apply. It might be advantageous for many farmers having problems with odors.

\section{REFERENCES}

1. Barbusinski, K., Kalemba, K., Kasperczyk, D., Urbaniec, K., Kozik, V. 2017. Biological methods for odor treatment - A review. Journal of Cleaner Production, 152, 223-241.

2. Biard, P., Couvert, A., Renner, C., Levasseur, J. 2010. Wet scrubbing intensification applied to hydrogen sulphide removal in waste water treatment plant. Canadian Journal of Chemical Engineering, 88 (4), 682-687.

3. Boumnijel, I., Ben Amor, H., Chekir, H., Hajji, N. 2016. Hydrogen sulphide removal from the effluents of a phosphoric acid production unit by absorption into chlorinated seawater under alkaline conditions. Comptes Rendus Chimie, 19 (4), 517-524.

4. Cartellieri, A., Thiesen, P., Niemeyer, B. 2005. Development of a basic procedure to design sorption processes. Waste Management, 25 (9), 985-993.

5. Ergas, S.J., Cárdenas-González, B. 2004. Biofiltration: past, present and future directions. BioCycle, $6,35-39$.

6. Freudenthal, K., Otterpohl, R., Behrendt, J. 2005. Absorption of odorous substances using selective gas-liquid separation processes. Waste Management, 25 (9), 117-126.

7. Gutarowska, B., Matusiak, K., Borowski, S., Rajkowska, A., Brycki, B. 2014. Removal of odorous compounds from poultry manure by microorganisms on perlite - bentonite carrier. Journal of Environmental Management, 141, 70-76.

8. Jugowar, L. J., Piotrkowski, M. 2012. Comparision of odour emission from different systems of keeping poultry. Journal of Research and Applications in Agricultural Engineering, 57 (3), 182-185.

9. Kulig, A., Lelicińska-Serafin, K., Podedworna, J., Sinicyn, G., Heidrich, Z., Czyżkowski, B. 2009. Inwentaryzacja źródeł odorantów w gospodarce ściekowej i odpadowej w Polsce oraz ocena ich uciążliwości na podstawie badań ankietowych. Przemysł Chemiczny, 88 (5), 484-492.

10. Łączyński, A., Krawiecka, L., Kuliś, M., Przypaśniak, J., Cieślak, A., Figaj, H., Wątroba E. 2011. Powszechny Spis Rolny 2010 - Zwierzęta gospodarskie i wybrane elementy metod produkcji zwierzęcej.

11. Matusiak, K., Oleksy, M., Borowski, S., Nowak, A., Korczyński, M., Dobrzański, Z., Gutarowska B. 2016. The use of Yucca schidigera and microbial preparation for poultry manure deodorization and hygienization. Journal of Environmental Management, 170, 50-59.

12. Mielcarek, W., Prociow, K., Warycha, J., Kacprzyk, R., Rutkowski, J., Czapka, T., Gryglewicz S., Subocz J. 2009. Construction and performance of a plasma reactor for odor neutralization. Przemysl Chemiczny, 88 (5), 516-519.

13. Mokhatab, S., Poe, W. A. 2012. Chapter 8 - Sulfur Recovery and Handling Handbook of Natural Gas Transmission and Processing (Second Edition). Boston: Gulf Professional Publishing.

14. ODORY - ABC. (2018). from http://www.odory. zut.edu.pl/szkola-olfaktometrii/odory-abc.html, 2018-01-09.

15. Piecuch, T., Kowalczyk, A., Kups, D., Gomolka, D. 2011. Method of Neutralization of Odours Arising During Mechanical Dewatering of Municipal Sewage Sludge. Rocznik Ochrona Srodowiska, 13, 747-768.

16. PN-EN 13725 Jakość powietrza. Oznaczanie stężenia zapachowego metodą olfaktometrii dynamicznej.

17. Schlegelmilch, M., Streese, J., Stegmann, R. 2005. Odour management and treatment technologies: An overview. Waste Management, 25 (9), 928-939.

18. Szynkowska, M. I., Wojciechowska, E., Węglińska, A., Paryjczak, T. 2009. Odourus emission. An environmental protection issue (in Polish). Przemysł Chemiczny, 88 (6), 712-720.

19. Wierzbińska, M., Modzelewski, W., Eugeniusz. 2015. The use of biofilters for deodorisation of the noxious gases. (in Polish). Inzynieria Ekologiczna, 41, 125-132.

20. Wysocka I., J., N. 2018. Odors in the air - analytical problems (in Polish). Analityka: nauka i praktyka, 2, accepted for printing. 